University of Nebraska - Lincoln

DigitalCommons@University of Nebraska - Lincoln

Agronomy \& Horticulture -- Faculty Publications

Agronomy and Horticulture Department

2008

\title{
Genetic background impacts soluble and cell wall-bound aromatics in brown midrib mutants of sorghum
}

\author{
Nathan A. Palmer \\ USDA-ARS, nathan.palmer@ars.usda.gov \\ Scott Sattler \\ USDA-ARS, Scott.Sattler@ars.usda.gov \\ Aaron J. Saathoff \\ USDA-ARS, asaathoff2@unl.edu \\ Deanna Funnell \\ USDA-ARS, Deanna.Funnell@ars.usda.gov \\ Jeffrey Pedersen \\ USDA-ARS, jpedersen1@unl.edu \\ See next page for additional authors
}

Follow this and additional works at: https://digitalcommons.unl.edu/agronomyfacpub

Part of the Plant Sciences Commons

Palmer, Nathan A.; Sattler, Scott; Saathoff, Aaron J.; Funnell, Deanna; Pedersen, Jeffrey; and Sarath, Gautam, "Genetic background impacts soluble and cell wall-bound aromatics in brown midrib mutants of sorghum" (2008). Agronomy \& Horticulture -- Faculty Publications. 139.

https://digitalcommons.unl.edu/agronomyfacpub/139

This Article is brought to you for free and open access by the Agronomy and Horticulture Department at DigitalCommons@University of Nebraska - Lincoln. It has been accepted for inclusion in Agronomy \& Horticulture -Faculty Publications by an authorized administrator of DigitalCommons@University of Nebraska - Lincoln. 
Authors

Nathan A. Palmer, Scott Sattler, Aaron J. Saathoff, Deanna Funnell, Jeffrey Pedersen, and Gautam Sarath 


\title{
Genetic background impacts soluble and cell wall-bound aromatics in brown midrib mutants of sorghum
}

\author{
Nathan A. Palmer $\cdot$ Scott E. Sattler • Aaron J. Saathoff $\cdot$ \\ Deanna Funnell · Jeffery F. Pedersen · Gautam Sarath
}

Received: 27 August 2008 / Accepted: 30 August 2008 / Published online: 16 September 2008

Springer-Verlag 2008

\begin{abstract}
Sorghum (Sorghum bicolor (L.). Moench) BMR-6 and BMR-12 encode cinnamylalcohol dehydrogenase and caffeic acid- $O$-methyltransferase, respectively. We have evaluated the impact of two $b m r$ alleles, $b m r-6$ and $b m r-12$, respectively, on soluble and wall-bound aromatics in near isogenic, wild-type (WT), bmr-6, bmr-12 and double-mutant (DM; $b m r-6$ and $b m r-12)$ plants in two genetic backgrounds, RTx430 and Wheatland. Immunoblots confirmed that COMT protein was essentially absent in $b m r-12$ and DM plants, but was present in $b m r-6$ and WT plants. In contrast, although CAD activity was not detected in $b m r-6$ and DM plants, proteins crossreacting to
\end{abstract}

Mention of trade names or commercial products in this publication is solely for the purpose of providing specific information and does not imply recommendation or endorsement by the U.S. Department of Agriculture.

Electronic supplementary material The online version of this article (doi:10.1007/s00425-008-0814-1) contains supplementary material, which is available to authorized users.

N. A. Palmer · S. E. Sattler · A. J. Saathoff · D. Funnell ·

J. F. Pedersen · G. Sarath $(\square)$

Grain, Forage and Bioenergy Research Unit,

USDA-ARS, University of Nebraska-Lincoln, East Campus,

314 Biochemistry Hall, Lincoln, NE 68583-0737, USA

e-mail: Gautam.Sarath@ars.usda.gov

N. A. Palmer · S. E. Sattler · A. J. Saathoff .

J. F. Pedersen · G. Sarath

Department of Agronomy and Horticulture,

University of Nebraska-Lincoln, East Campus,

Lincoln, NE 68583-0937, USA

D. Funnell

Department of Plant Pathology,

University of Nebraska-Lincoln, East Campus,

Lincoln, NE 68583-0937, USA
anti-CAD sera were found in stem extracts from all genotypes. In both sorghum backgrounds, WT plants had lowest amounts of free aromatics, higher levels of cell wall-bound pCA and FA esters and guaiacyl (G), syringyl (S), and $p$ hydroxyphenyl $(\mathrm{H})$ lignins. Soluble aromatics and cell wall phenolic ester content in Wheatland DM plants resembled that of Wheatland $b m r-6$ plants, whereas in the RTx430 background, levels of these components in the DM plants more closely resembled those observed in $b m r-12$ plants. In both backgrounds, $b m r-6$ plants exhibited reduced levels of $\mathrm{G}, \mathrm{S}$, and $\mathrm{H}$ lignins relative to WT, and increased incorporation of G-indene into lignin. In $b m r-12$ plants, there was greater incorporation of G- and 5-hydroxyguaiacyl (5OHG) lignin into cell walls. Histochemical staining of internode sections from Wheatland plants indicated that apparent lignification of cortical sclerenchyma and vascular bundle fibers was greatest and most uniform in WT plants. Relative staining intensity of these tissues was decreased in $b m r-6$, followed by $b m r-12$ plants. DM plants exhibited poor staining of cortical sclerenchyma and vascular bundle fibers.

Keywords Brown midrib - Double-mutant · Lignin · Phenolics $\cdot$ Sorghum bicolor $\cdot$ Thioacidolysis

$\begin{array}{ll}\text { Abbreviations } & \\ \text { 5-OHG-lignin } & \text { 5-Hydroxyguaiacyl unit } \\ \text { AscPx } & \text { Ascorbate peroxidase } \\ b m r & \text { Brown midrib } \\ \text { pCA } & p \text {-Coumaric acid } \\ \text { CAD } & \text { Cinnamylalcohol dehydrogenase } \\ \text { CafA } & \text { Caffeic acid } \\ \text { CCoAOMT } & \text { Caffeoyl coenzyme A } O \text {-methyltransferase } \\ \text { COMT } & \text { Caffeic acid } O \text {-methyltransferase } \\ \text { DM } & \text { Double-mutant }(b m r-6 \text { and } b m r-12)\end{array}$




$\begin{array}{ll}\text { FA } & \text { Ferulic acid } \\ \text { G-lignin } & \text { Guaiacyl unit } \\ \text { GCMS } & \text { Gas chromatography-mass spectrometry } \\ \text { H-lignin } & p \text {-Hydroxyphenyl unit } \\ \text { HPLC } & \text { High performance liquid chromatography } \\ \text { S-lignin } & \text { Syringyl unit } \\ \text { SA } & \text { Sinapic acid } \\ \text { SyrA } & \text { Syringic acid } \\ \text { VA } & \text { Vanillic acid } \\ \text { WT } & \text { Wild-type }\end{array}$

\section{Introduction}

There has been an explosion of interest in developing plants specifically for conversion to biofuels within the last few years. Much of this interest has been spurred by a need to find renewable sources of energy to partially replace petroleum while mitigating levels of greenhouse gases (Schmer et al. 2008; Sarath et al. 2008). Sorghum (Sorghum bicolor (L.) Moench), grown for grain, forage, or molasses, has been proposed to fill this niche, because it is a diploid C4species with heat and drought tolerance, and has a sequenced genome. These characteristics make sorghum attractive for development as a model biomass crop (Sarath et al. 2008). Another advantageous feature of sorghum for bioenergy is the presence of brown midrib $(\mathrm{bmr})$ mutations that can reduce lignin content and increase forage digestibility in animals (Cherney et al. 1991; Oliver et al. 2005a). Increased forage digestibility is negatively correlated with lignin content in a number of grass species, including potential bioenergy crops such as switchgrass, sorghum, and reed canary grass (Casler et al. 2002; Oliver et al. 2005a, b; Pedersen et al. 2005; Casler and Jung 2006). Lowered lignin also has been shown to increase conversion efficiency of biomass into ethanol (Dien et al. 2006; Chen and Dixon 2007).

Two sorghum $b m r$ genes have been characterized at the molecular level. Pillonel et al. (1991) characterized sorghum $b m r-6$ as a mutation principally affecting cinnamyl alcohol dehydrogenase (CAD) activity, although a mutation in the CAD gene has not yet been identified. Plants carrying this mutation displayed reduced levels of lignin and incorporation of cinnamylaldehydes into the lignin polymer. Interestingly, these $b m r-6$ plants also displayed decreased levels of caffeic acid $O$-methyl transferase (COMT) (Pillonel et al. 1991). Bout and Vermerris (2003) identified a nonsense mutation in a COMT gene responsible for the $b m r-12$ phenotype in sorghum plants. This same COMT gene also contained two other nonsense mutations responsible for $b m r-18$ and $b m r-26$, indicating that $b m r-12,18$, and 26 were alleles of a single locus. COMT mRNA levels were significantly reduced in these plants (Bout and Vermerris 2003).
Lignin is a heterogeneous polymer arising through crosslinking of hydroxylated and methoxylated derivatives biosynthesized from cinnamic acid. Higher plant lignin has generally been categorized into three primary subtypes, denoted as $p$-hydroxyphenyl or H-lignin, guaiacyl or G-lignin, and syringyl or S-lignin. H-lignin (or $\mathrm{H}$-unit) arises from $p$-coumaryl alcohol, G-lignin from coniferyl alcohol, and S-lignin from sinapyl alcohol (Boerjan et al. 2003). However, plants have the capacity to incorporate a range of molecules such as 5-hydroxyconiferyl alcohol and different cinnamylaldehydes into the lignocellulosic matrix (Humphreys et al. 1999; Anterola and Lewis 2002; Boerjan et al. 2003; Barrière et al. 2004; Shadle et al. 2007; Rastogi and Dwivedi 2008). Grasses also contain significant amounts of $p$-coumaric acid (pCA) and ferulic acid (FA), predominantly crosslinked to cell wall lignin and polysaccharide through ester and ether linkages (Grabber et al. 1991; Dixon et al. 2001; Chen et al. 2002; Boerjan et al. 2003; Grabber and Lu 2007).

A generalized scheme integrating the two sorghum $\mathrm{bmr}$ mutations into the broader framework of lignin biosynthesis (Dixon et al. 2001; Boerjan et al. 2003; Rastogi and Dwivedi 2008) is shown in Fig. 1. Using this figure as a guide, it can be postulated that a null allele of COMT ( $\mathrm{bmr}$ 12) will lower the amount of S-lignin, principally through a lack of appropriate syringyl (sinapyl) moieties. A lack of utilization of 5-hydroxyconiferyl aldehyde (a presumed substrate for sorghum COMT) could increase the amount of 5-hydroxyconiferyl alcohol through the action of CAD, potentially leading to higher incorporation of 5-hydroxyguaiacyl (5-OHG) moieties into lignin in $b m r-12$ plants (Fig. 1). Similarly, if CAD is a null allele in $b m r-6$ plants, it is expected to lower total lignin by blocking the synthesis of alcohol (monolignol) derivatives. Consequently, $b m r-6$ plants could contain increased levels of aldehyde derivatives in their lignin as compared to the WT plants. However, if CAD activity is lowered, but not abolished in bmr-6 plants, there may or may not be observed changes in total lignin and lignin subtypes. Finally, changes in lignin content and composition can be expected in tissues that are lignified at maturity, such as the xylem, vascular bundle fiber sheaths, and cortical schlerenchyma. Earlier studies using leaf tissues have confirmed some of these predictions showing that $b m r-6$ and $b m r-12$ plants have less lignin, have reduced amounts of cell wall-bound pCA esters, and have altered S- to G-lignin ratios as compared to wild-type plants (Akin et al. 1986; Pillonel et al. 1991; Bout and Vermerris 2003).

The combination of $b m r$ mutants in near-isogenic lines in different genetic backgrounds of sorghum has not been characterized. Such data are necessary for the development of $b m r$-sorghum cultivars for bioenergy. The present study is a first report of comparisons of the phenolic profiles as a 


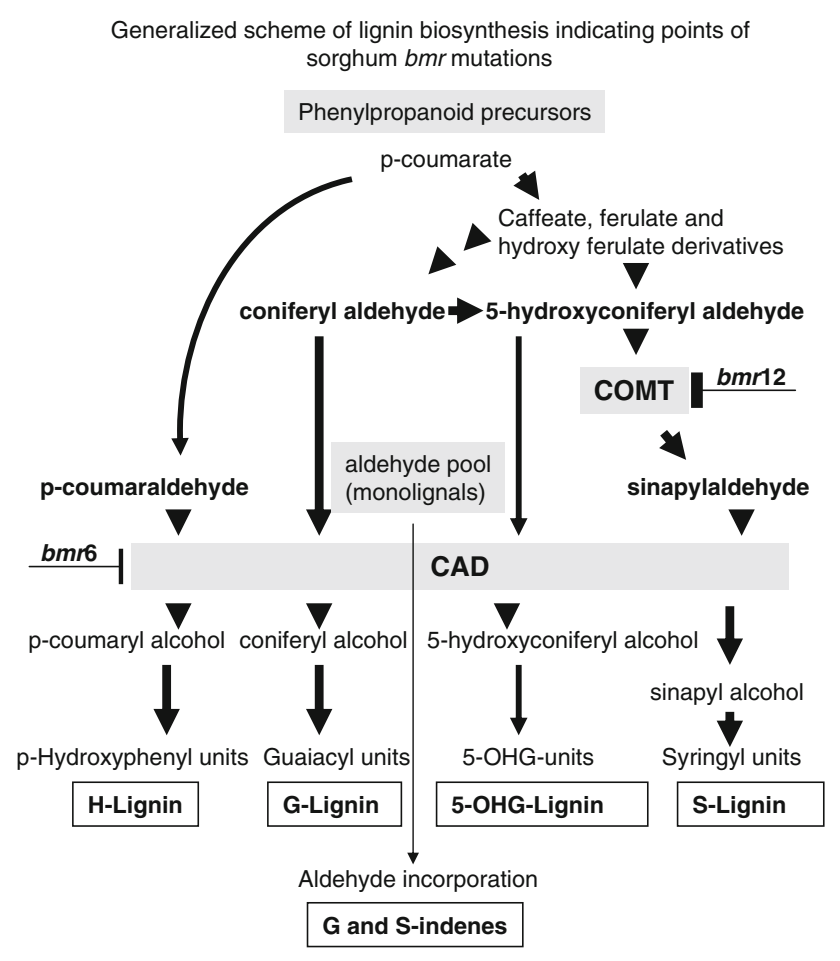

Fig. 1 Generalized scheme for lignin biosynthesis in sorghum, and the anticipated effects of the $b m r-6$ and $b m r-12$ mutations on lignin incorporation into cell walls. Phenylpropanoid precursors can serve as substrates COMT and CAD. In $b m r-12$ plants, COMT activity is compromised, potentially leading to reduced levels of sinapylaldehyde and expected reduction in S-lignin and possibly an increase in incorporation of 5-OHG-lignin. In contrast, $b m r-6$ is associated with compromised CAD activity. CAD catalyzes the final conversion of monolignals (aldehydes) to monolignols (alcohols). Lowered or loss of CAD activity is expected to result in a low overall incorporation of monolignols into lignin. In $b m r-6, b m r-12$, and DM plants, varying levels of monolignals could be incorporated into cell walls shown by an arrow that circumvents CAD-catalyzed generation of monolignol precursors

result of the $b m r-6$ and the $b m r-12$ alleles, singly or in combination and in two different genetic backgrounds. Our data indicate effects of genetic background on the impact of $\mathrm{bmr}$ mutants on both soluble and wall-bound aromatic constituents in sorghum.

\section{Materials and methods}

Preparation of plant materials

The genetic stocks used in this study are publicly released and freely available from the USDA, ARS. Development of the single- and double-mutant stocks is described by Pedersen et al. (2006, 2008). The double-mutant genetic stocks are $\mathrm{F}_{4}$ selections from crosses between the single-mutant sister-lines. Seeds were sown in a soil-mix consisting of soil:peat moss:vermiculite:pearlite:sand (4:1:1:1:1), grown in $28 \mathrm{~cm}$ pots under a $16 \mathrm{~h}$ day regimen and fertilized as needed with a fertilizer containing 11:15:11 (N:P:K; Fertilome Gardner's Special, William's Garden Center, Lincoln, $\mathrm{NE}$ ). Seedlings were thinned to two plants per pot. Following emergence of the inflorescence (about 50 days after planting), the first (top) and fourth (bottom) internodes below the peduncle were harvested from at least six plants, pooled, oven-dried at $50^{\circ} \mathrm{C}$ and ground to pass through $1 \mathrm{~mm}$ screens using a Wiley mill.

\section{Immunoblotting}

Immature internodes from 40-day-old greenhouse-grown sorghum plants were ground to a powder using liquid nitrogen in a mortar and pestle and stored at $-80^{\circ} \mathrm{C}$. Small aliquots $(\sim 100 \mathrm{mg})$ of pulverized stems were extracted using $50 \mathrm{mM}$ Tris-Cl, $\mathrm{pH} 7.4$, containing $10 \%$ (w/v) glycerol, $2 \%(\mathrm{w} / \mathrm{v})$ SDS, and 5\% (v/v) 2-mercaptoethanol, and the crude homogenate was centrifuged for $10 \mathrm{~min}$ at $13,500 \times \mathrm{g}$. Protein concentration of the clarified stem homogenates was determined using a colorimetric assay on acetone-precipitated proteins (BCA assay, Pierce Chemical Co., IL). Approximately $30 \mu \mathrm{g}$ of total protein were loaded from each sample and separated on $12 \%$ acrylamide gels in the presence of SDS (Laemmli 1970). Separated proteins were electroblotted to nitrocellulose membranes and probed with antibodies (Xiang et al. 2004). Antibodies were generated to soybean root nodule ascorbate peroxidase (Dalton et al. 1993) and to recombinant proteins produced in E. coli to the following ESTs: DN143131 = switchgrass CAD; DN143927 = switchgrass CCOMT; CX607415 = sorghum COMT. The coding sequence for COMT was arbitrarily truncated into $\mathrm{N}$-terminal and $\mathrm{C}$-terminal nonoverlapping polypeptides and used to generate polyclonal antibodies in rabbits ( $\mathrm{N}$-terminal) and guinea pigs ( $\mathrm{C}$-terminal).

\section{CAD assays}

Young sorghum internodes (internode below peduncle) were ground to a powder using dry-ice and a coffee grinder. Approximately $1 \mathrm{~g}$ of this powder was extracted by grinding in a mortar and pestle with $2.5 \mathrm{~mL}$ of $100 \mathrm{mM}$ Tris-Cl buffer, $\mathrm{pH} 8.8$, containing $2 \mathrm{mM}$ DTT and a protease inhibitor cocktail (Sigma-Aldrich, St Louis, MO). The homogenate was filtered through one layer of miracloth and centrifuged at $13,500 \mathrm{rpm}$ at $4^{\circ} \mathrm{C}$ for $10 \mathrm{~min}$ to obtain a crude extract. Two milliliters of the crude extract was made to $80 \%$ saturation with solid ammonium sulfate, and the salt was dissolved by gentle mixing. Tubes were placed on ice for $1 \mathrm{~h}$ and precipitated proteins collected by centrifugation at $13,500 \mathrm{rpm}, 4^{\circ} \mathrm{C}$, for $15 \mathrm{~min}$. The liquid was decanted and tubes drained by inversion for $3 \mathrm{~min}$. The residual protein pellet was resolubilized in $0.3 \mathrm{~mL}$ of 
$50 \mathrm{mM}$ Tris-Cl buffer, $\mathrm{pH} 7.5$, containing $5 \mathrm{mM}$ DTT and $10 \%$ ethylene glycol, then briefly centrifuged to pelletinsoluble materials. Triplicate $30-\mu \mathrm{L}$ aliquots of extract were assayed for CAD activity at $34^{\circ} \mathrm{C}$. The final assay volume was $200 \mu \mathrm{L}$ and contained $100 \mathrm{mM}$ Tris- $\mathrm{Cl}$ buffer, $\mathrm{pH}$ 8.8, $0.2 \mathrm{mM} \mathrm{NADP}^{+}$, and $0.1 \mathrm{mM}$ coniferyl alcohol. Absorbance change over $45 \mathrm{~min}$ was monitored at both 340 and $400 \mathrm{~nm}$ using a Molecular Devices Spectramax Plus spectrophotometer (Molecular Devices, Sunnyvale, CA). Initial attempts to assay crude extracts directly resulted in minimal activity and were not pursued further.

\section{Analyses of soluble aromatics}

Soluble aromatic components were extracted into aqueous methanol and analyzed using a Beckman programmable gradient HPLC as described previously (Sarath et al. 2007). Phenolic components in peaks resolved by HPLC were identified by collecting the eluate under major peaks, followed by analysis by gas chromatography-mass spectrometry (GCMS). Eluates were vacuum-dried and hydrolyzed with $100 \mu \mathrm{l} 2 \mathrm{M} \mathrm{NaOH}$ for $4 \mathrm{~h}$ at room temperature. Released aromatics were extracted into ethyl acetate after acidification with $2 \mathrm{M} \mathrm{HCl}$. Ethyl acetate extracts were vacuum-dried and analyzed by GCMS, using an Agilent G2570A integrated GCMS system equipped with a G2913A autoinjector module, 6850 Series II GC, and a 5973 Network Mass spectrometer (Agilent, Palo Alto, CA). Total aromatics present in aqueous methanol extracts from sorghum stems were identified as described above, but without prior separation by HPLC.

Both soluble phenolics and aromatics obtained as described above, and ester-linked pCA and FA extracted from purified cell walls (Iiyama et al. 1990), were analyzed as their silyl esters using $\mathrm{N}, \mathrm{O}$-bis-(trimetylsilyl)trifluoroacetamide and trimethylchlorosilane reagent according to manufacturer-recommended protocol (Pierce Chemical Company, Rockford, IL; Sarath et al. 2007). Standard curves for different phenolics were generated using authentic compounds obtained from commercial vendors. Triplicate extracts were analyzed for each sample. All chemical analyses were repeated at least twice. Statistical analyses were performed using routines available in Microsoft Excel or using PROC MIXED in SAS (Littell et al. 1996). Wallbound phenolic ethers were not measured.

\section{Thioacidolysis}

Thioacidolysis (Lapierre et al. 1986) followed by GCMS (for example, Kim et al. 2002) was used to evaluate the relative composition of etherified $\mathrm{H}_{-}, \mathrm{G}-$, and S-lignin and other lignin components in the sorghum genotypes. Ground stem material (Wiley mill, $1 \mathrm{~mm}$ screen) was first extracted by washing twice in water for $30 \mathrm{~min}$, followed by two $30-$ min washes in $100 \%$ EtOH. Washed materials were dried in a vacuum centrifuge (Labconco Centrivap, Kansas City, MO) after addition of $1 \mathrm{~mL}$ acetone. Approximately $20 \pm 1 \mathrm{mg}$ of washed dried cell wall material was placed into $10 \mathrm{~mL}$ Reacti-vials (Pierce Chemical Co, Rockford, IL) and transferred to a fume hood. To each vial, $7 \mathrm{~mL}$ of a solution containing $10 \%$ (v/v) ethanethiol, $2.5 \%(\mathrm{v} / \mathrm{v}) \mathrm{BF}_{3}$-etherate in dioxane was added. Vials were capped tightly with silicon/teflon caps and placed in a heating block and incubated at $100^{\circ} \mathrm{C}$ for $4 \mathrm{~h}$, with mixing by gentle swirling every hour. After hydrolysis, solution in each vial was transferred to a $50-\mathrm{mL}$ polypropylene tube containing $1 \mathrm{~mL}$ of $0.4 \mathrm{M} \mathrm{NaHCO} 3$ and $200 \mu \mathrm{L}$ of $1.25 \mathrm{mg} / \mathrm{mL}$ docosane in dichloromethane as an internal standard. Reacti-vials were rinsed with approximately $9 \mathrm{~mL}$ of megapure water and added to the sample in the $50-\mathrm{mL}$ tube. The volume in the tube was brought upto $25 \mathrm{~mL}$ with megapure water. This aqueous solution was extracted five times with $15 \mathrm{~mL}$ of dichloromethane each time by vigorous shaking, followed by a 10-min incubation to allow separation of the phases. The organic lower layer was then transferred with a transfer pipette into a new $50-\mathrm{mL}$ polypropylene tube. The aqueous phase was re-extracted twice using $10 \mathrm{~mL}$ of dichloromethane each time. Approximately $0.5 \mathrm{~g}$ of sodium sulfate was added to the pooled organic phase, and the liquid was transferred to a 50-mL polypropylene tube and evaporated to dryness using a gentle stream of air. The dried thioacidolysis products were resuspended in $1 \mathrm{~mL}$ of dichloromethane, and triplicate $2 \mu \mathrm{L}$ aliquots of this solution were derivatized using $\mathrm{N}, \mathrm{O}$-bis-(trimetylsilyl)trifluoroacetamide and trimethylchlorosilane and analyzed in triplicate by GCMS using the conditions as described by Zuo et al (2002). Lignin components were measured based on the peak area of major ions $(\mathrm{m} / \mathrm{z})$ as follows: H-Ligin: 239; G-Lignin: 269; S-Lignin: 299; hG-Lignin: 357; G-Indene: 354; S-Indene: 323 (Kim et al. 2002; Katsuyoshi et al. 2003). The peak area of the internal standards docosane $(\mathrm{m} / \mathrm{z} 57)$ (added at the time of tissue extraction) and toluic acid (added at the time of derivatization; $\mathrm{m} / \mathrm{z}$ 193) were used for the normalization of peak areas between samples.

\section{Microscopy}

The internode below the peduncle was excised from five plants from each Wheatland $b m r$ line and the WT line, cut transversely into approximately $2 \mathrm{~mm}$ slices and fixed for $24 \mathrm{~h}$ in $3.7 \%$ formaldehyde. Fixed tissues were dehydrated in a graded series of alcohol and then embedded in paraffin. Sections $20 \mu \mathrm{m}$ thick were cut and adhered to glass slides (Veterinary Diagnostic Center, University of NebraskaLincoln). Prior to staining, sections were deparaffinized in 
xylene, processed through a graded alcohol series, and washed twice with water (5 min each). Sections were stained with freshly prepared diazotized nitroaniline (Akin et al. 1990) for $5 \mathrm{~min}$, washed in water, mounted in $20 \%$ glycerol, and viewed using a Zeiss Axioskop microscope (Carl Zeiss, Jena, Germany) attached to a digital camera (Diagnostics Instruments, Sterling Heights, MI). All sections were imaged identically using camera software settings (SPOT, Diagnostics Instruments, Sterling Heights, MI). For each genotype, internodes from five plants were cut, fixed, pooled, embedded in paraffin, sectioned, and two to three slides were stained and viewed. Representative images are shown.

\section{Results}

Levels of lignin biosynthetic proteins in stem extracts

Stem protein extracts from different genotypes were separated by gel electrophoresis, transferred to nitrocellulose membranes, and probed with antibodies to COMT, CAD, CCoAOMT, and AscPx proteins. Immunoreactive bands at the expected size of COMT were detected with the polyclonal antibodies against either the C-terminal fragment or the N-terminal fragment of COMT in the stem extracts from WT and bmr-6 plants (Fig. 2; Rb COMT and GpCOMT). Lanes containing the bmr-12 and double-mutant stem extracts lacked visible bands in either background when probed with polyclonal antibodies to the N-terminal fragment of COMT generated in rabbits (Fig. 2; RbCOMT), but faint bands of the expected size were observed in extracts from bmr-12 and double-mutant RTx430 plants, probed with COMT antibodies raised in guinea pigs (Fig. 2; Gp-COMT, arrow). No significant differences were observed in immunoreactive band intensities when stem extracts from all plant genotypes were tested with polycolonal antibodies against CAD, CCoAMT, and AscPX (Fig. 2).

\section{CAD activity}

Internode extracts from the different sorghum genotypes were assayed for CAD activity using coniferyl alcohol and $\mathrm{NADP}^{+}$as substrates. Activity was detected in extracts from WT and $b m r-12$ plants $(24.6 \pm 2.2$ and $22.2 \pm 1.6 \mu \mathrm{mol}$ of coniferyl aldehyde produced per minute per milligram of protein for Wheatland WT and $b m r-12$ plants and $18.6 \pm 2.5$ and $13.2 \pm 0.6 \mu \mathrm{mol}$ of coniferyl aldehyde produced per minute per milligram of protein for RTx430 WT and bmr-12 plants, respectively). CAD activity was below the detection limits under the conditions of our assay in extracts obtained from $b m r-6$ and DM plants.

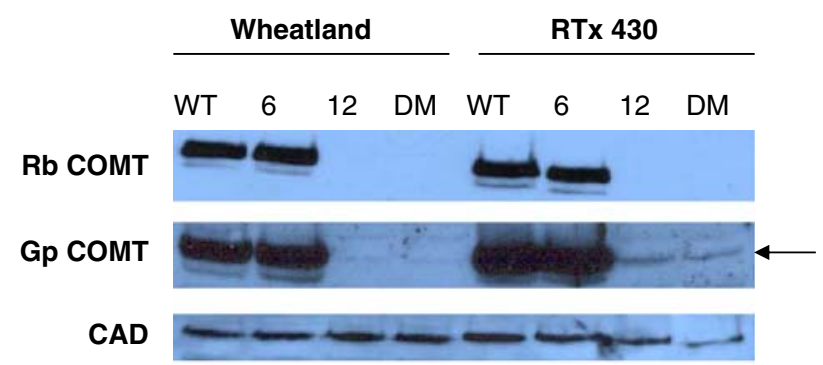

CCOAOMT

AscPx

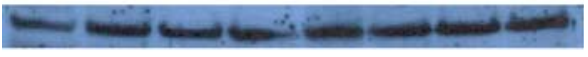

Fig. 2 Immunoblots of protein extracts from stems of Wheatland and RTx430 near-isogenic $b m r$ and WT plants. Proteins in stem extracts were separated by SDS-PAGE and transferred to nitrocellulose membranes. Membranes were probed with different antibodies. Arrow points to a faint band in extracts of $b m r-12$ and double-mutant RTx430 plants detected following crossreaction with polyclonal antibodies to the C-terminus of the COMT protein. WT wild type, $D M$ double-mutant. $\mathrm{Rb}$-COMT, antibodies raised to recombinant $\mathrm{N}$-terminal polypeptide of caffeoyl-O-methyltransfrease in rabbits. Gp-COMT, antibodies raised to a recombinant $\mathrm{C}$-terminal polypeptide of COMT in guinea pigs. CAD, antibodies raised to recombinant cinnamyl alcohol dehydrogenase polypeptide in guinea pigs. CCOMT, antibodies raised to recombinant caffeoyl-CoA-O-methyltransferase in rabbits. AscPx, antibodies raised to purified soybean root nodule ascorbate peroxidase. This antibody was used as a loading and transfer control. Other relevant details are presented in "Materials and methods"

Analysis of soluble aromatics

Initial analysis of soluble phenolic and related aromatic compounds present in stem extracts from the different genotypes by HPLC indicated that top internodes contained greater amounts and numbers of peaks as compared to the bottom nodes for the genotypes analyzed (Supplementary Fig. S1). However, these peaks were not readily identifiable due to significant complexity of the absorbance patterns, suggesting that these peaks contained mixtures of different esters and conjugates. GCMS analysis of individual HPLC peaks indicated the presence of multiple aromatic compounds in several of the HPLC peaks (Supplementary Fig. S1). To overcome this limitation in our assays, we directly quantified the content and diversity of aromatics in the top internodes of the plants.

GCMS analyses were performed on methanolic extracts of tissues that had been subjected to room temperature alkaline hydrolysis to generate free aromatic compounds (Table 1). Significant differences in free phenolic acid content were noticed between the different genotypes in both genetic backgrounds. Soluble extracts of WT Wheatland and RTX430 plants contained high levels of pCA ( $>50 \%$ of total) and FA ( $\sim 23 \%$ of total) and lower levels of VA, SA, 
Table 1 Soluble aromatics in sorghum internodes

\begin{tabular}{|c|c|c|c|c|c|c|c|}
\hline \multirow[t]{2}{*}{ Genotype } & \multicolumn{7}{|c|}{ Phenolic acid } \\
\hline & pCA & FA & VA & SA & SyrA & CafA & Total \\
\hline \multicolumn{8}{|l|}{ Wheatland } \\
\hline WT & $217.0 \mathrm{a}$ & $91.7 \mathrm{a}$ & $21.9 \mathrm{a}$ & $22.4 \mathrm{a}$ & $18.3 \mathrm{a}$ & $21.2 \mathrm{a}$ & $396.2 \mathrm{a}$ \\
\hline$b m r-6$ & $166.0 \mathrm{~b}$ & $856.3 \mathrm{~b}$ & $124.7 \mathrm{~b}$ & $177.8 \mathrm{~b}$ & $76.7 \mathrm{~b}$ & $67.9 \mathrm{~b}$ & $1,469.4 \mathrm{~b}$ \\
\hline$b m r-12$ & $313.1 \mathrm{c}$ & $176.3 \mathrm{a}$ & $33.8 \mathrm{a}$ & $36.7 \mathrm{a}$ & $16.4 \mathrm{a}$ & $67.7 \mathrm{~b}$ & $644.0 \mathrm{c}$ \\
\hline $\mathrm{DM}$ & $113.8 \mathrm{~d}$ & $389.8 \mathrm{~d}$ & $93.8 \mathrm{~b}$ & $151.0 \mathrm{~b}$ & $46.1 \mathrm{c}$ & $22.5 \mathrm{a}$ & $821.2 \mathrm{c}$ \\
\hline $\operatorname{LSD}_{0.05}$ & 40.3 & 139.7 & 33.9 & 32.6 & 11.0 & 11.1 & 242.5 \\
\hline \multicolumn{8}{|l|}{$\mathrm{RTx} 430$} \\
\hline WT & $209.8 \mathrm{a}$ & $94.3 \mathrm{ab}$ & $27.3 \mathrm{a}$ & $0.0 \mathrm{a}$ & $17.3 \mathrm{a}$ & $55.0 \mathrm{a}$ & $403.8 \mathrm{a}$ \\
\hline$b m r-6$ & $111.7 \mathrm{~b}$ & $270.2 \mathrm{c}$ & $170.0 \mathrm{~b}$ & $79.8 \mathrm{~b}$ & $69.1 \mathrm{~b}$ & $28.8 \mathrm{~b}$ & $729.7 \mathrm{~b}$ \\
\hline$b m r-12$ & $159.5 \mathrm{c}$ & $96.5 b$ & $61.6 \mathrm{c}$ & $27.6 \mathrm{c}$ & $10.5 \mathrm{c}$ & $64.3 \mathrm{a}$ & $421.5 \mathrm{a}$ \\
\hline DM & $205.6 \mathrm{a}$ & $80.1 \mathrm{a}$ & $22.7 \mathrm{a}$ & $37.0 \mathrm{c}$ & $13.1 \mathrm{~d}$ & $44.9 \mathrm{c}$ & $403.4 \mathrm{a}$ \\
\hline $\mathrm{LSD}_{0.05}$ & 23.5 & 15.0 & 35.9 & 11.4 & 2.1 & 10.0 & 50.8 \\
\hline
\end{tabular}

The values are given in $\mu \mathrm{g}$ acid $\mathrm{g}^{-1}$ dry weight, and are the means of three independent extractions of pooled stem tissues. DM $=b m r 6-b m r 12$. Within each background and for each component, values followed by different letters were significantly different at $P \leq 0.05$. LSD ${ }_{0.05}$ is given for each analysis

$p C A$-coumaric acid, $F A$ ferulic acid, $V A$ vanillic acid, $S A$ sinapic acid, SyrA syringic acid, CafA caffeic acid

SyrA, and CafA (Table 1). SA was not detected in the soluble fraction of the WT RTx430 plants.

The level of free soluble pCA was significantly lower, and the levels of other phenolic acids were significantly higher in $b m r-6$ plants relative to the other genotypes. In the Wheatland background, FA content in $b m r-6$ plants was approximately 9.3-fold greater than that in WT plants (856.3 and $91.7 \mu \mathrm{g}$ acid $\mathrm{g}^{-1}$ dry wt internodes, respectively; Table 1). In the RTx430 background, $b m r-6$ plants exhibited a 2.9-fold increase in the amounts of FA relative to WT plants. VA, SA, and SyrA levels in the $b m r-6$ plants also were significantly increased (Table 1). In both backgrounds, $b m r-6$ plants had the highest levels of free aromatics as compared to the other genotypes. Wheatland $b m r-6$ plants contained threefold greater amounts of free CafA than WT Wheatland plants. In contrast, CafA levels were reduced approximately twofold in RTx430 bmr-6 plants relative to WT plants.

Genetic background effects were observed in $b m r-12$ and DM plants as well. In $b m r-12$ Wheatland plants, total soluble phenolic acids were approximately twofold greater than in WT plants and approximately 2.5-fold less than the levels observed in bmr-6 Wheatland plants. In the RTx430 background, total phenolic acid levels were similar between $b m r-12$ and WT plants (419 and $403 \mu \mathrm{g} \mathrm{g}^{-1}$ dry wt, respectively), and the levels were approximately 1.8 -fold higher in $b m r-6$ plants $\left(729 \mu \mathrm{g} \mathrm{g}^{-1}\right.$ dry wt) than $b m r-12$ or WT. Levels of VA, SA, and CafA were higher in $b m r-12$ plants relative to WT plants in both backgrounds.

Total amounts of soluble aromatics were lower in DM Wheatland plants than in $b m r-6$ Wheatland (approximately
818 and $1,470 \mu \mathrm{g} \mathrm{g}^{-1}$ dry wt for plants, respectively). However, DM Wheatland plants contained a soluble aromatic profile similar to $b m r-6$ Wheatland plants; FA constituted approximately $47 \%$ of total measured compounds. The levels of VA, SA, and SyrA were also higher, but the level of pCA was significantly decreased in DM plants relative to WT plants. In contrast, soluble aromatic levels and profile of the DM RTx 430 plants more closely resembled those observed for $b m r-12$ and WT plants than for $b m r-6$ plants (Table 1).

GCMS analysis of wall-bound esterified pCA and FA

To determine how $b m r$ mutants impacted cell wall-bound pCA and FA esters in the near-isogenic lines, washed cell walls from WT, bmr-6, bmr-12, and DM plants in both Wheatland and RTx430 backgrounds were extracted for phenolic esters and analyzed by GCMS (Fig. 3a, b).

Wheatland WT plants had approximately 3.9 -fold more

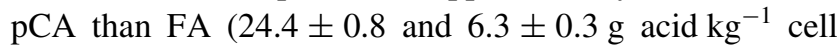
walls, respectively; Fig. 3a). In Wheatland $b m r-6$ plants, level of pCA was reduced to approximately 2.9-fold relative to WT cell walls, but FA levels were relatively unchanged compared to WT, with 1.3-fold more pCA than FA in the cell walls of $b m r-6$ Wheatland plants. In $b m r-12$ Wheatland plants, pCA amounts were reduced 1.7 -fold relative to WT levels $\left(14 \pm 0.6\right.$ and $24.4 \pm 0.8 \mathrm{~g}$ acid kg $\mathrm{kg}^{-1}$ cell walls, respectively). Wall-bound FA levels were increased 1.25-fold in $b m r-12$ plants compared to Wheatland WT and $b m r-6$ plants. In the Wheatland DM plants, the wall-bound phenolic esters signature was similar to that 

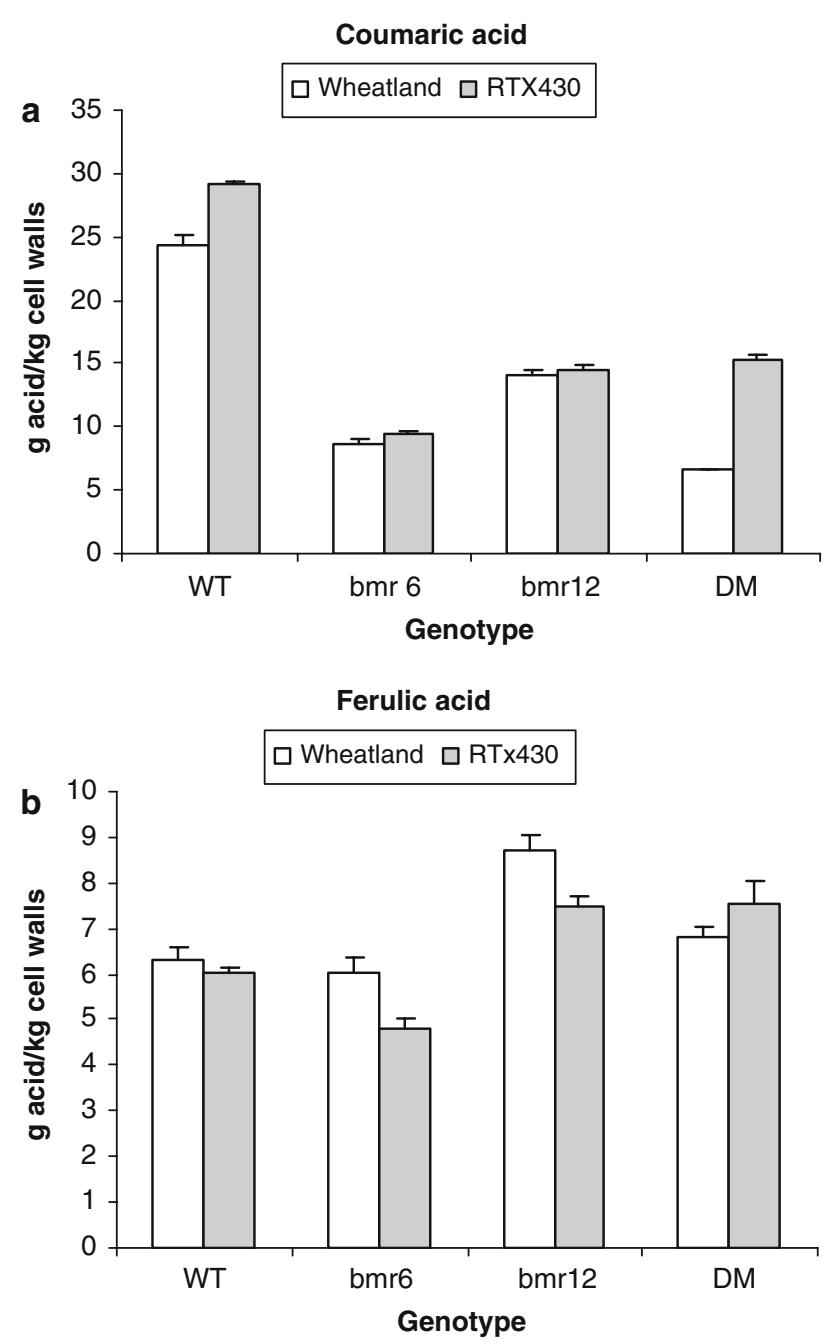

Fig. 3 Wall-bound 4-coumaric (pCA) and ferulic (FA) esters in Wheatland (white bars) and RTx430 (gray bars) WT and near-isogenic $b m r$ plants. Levels of pCA and FA esters in washed cell walls from mature (fourth) internodes of sorghum plants were analyzed by GCMS as described in "Materials and methods." a Wall-bound esterified pCA; b Wall-bound esterified FA. $D M$ double-mutant

found in $b m r-6$ plants; the level of pCA was reduced to 0.9 the level of FA (Fig. 3a).

In stems of WT RTx 430 plants, there was approximately fivefold more pCA than FA $\left(29.2 \pm 0.2 \mathrm{~g} \mathrm{pCA} \mathrm{kg}^{-1}\right.$ cell walls and $6.0 \pm 0.1 \mathrm{~g} \mathrm{FA} \mathrm{kg}^{-1}$ cell walls, respectively) (Fig. 3b). In bmr-6 RTx430 plants, pCA and FA levels were reduced 1.5 - and 3.0-fold, respectively, relative to RTx430 WT plants. RTx430 bmr-6 plants had only 1.3-fold more pCA than FA. In $b m r-12$ RTx 430 plants, pCA levels were reduced twofold relative to those in WT plants $\left(14.5 \pm 0.4 \mathrm{~g} \mathrm{pCA} \mathrm{kg}^{-1}\right.$ cell walls), but FA levels were increased approximately 1.2 -fold relative to those in WT stems $\left(8.7 \pm 0.3 \mathrm{~g} \mathrm{FA} \mathrm{kg}^{-1}\right.$ cell walls). There was approximately 1.7 -fold more pCA than FA in RTx430 bmr-12 plants. Changes in cell wall-bound pCA and FA levels in the RTx430 double-mutant plants were similar to those found in $b m r-12$ plants (Fig. 3b). pCA levels were decreased to about 2.1-fold relative to WT stems, and levels for FA were increased 1.2-fold relative to WT $(7.5 \pm 0.5 \mathrm{~g}$ FA $\mathrm{kg}^{-1}$ cell walls in double-mutant vs. $6.0 \pm 0.1 \mathrm{~g} \mathrm{FA}$ $\mathrm{kg}^{-1}$ cell walls in WT).

Thioacidolysis of sorghum cell walls

Representative scans of the marker ions used to calculate the relative levels of the different lignin monomers are shown in Fig. 4. For clarity, only data from the WT and DM RTX430 plants are shown, but similar data were collected for all the genotypes. GCMS scans from WT plants showed prominent ions at $\mathrm{m} / z, 269$ for G-lignin and $\mathrm{m} / \mathrm{z} 299$ for S-lignin (Fig. 4a, b). Abundance of these peaks was greatly diminished in the DM plants. Abundance of ion characteristic of H-lignin $(\mathrm{m} / \mathrm{z}, 239$; Fig. 4c) was approximately 100 -fold less in WT plants as compared to the signals observed for G- and S-lignin marker ions in these plants. Ions associated with 5-OHG-lignin (arising from 5-hydroxyconiferyl alcohol; Lam et al. 1996; Rastogi and Dwivedi 2008) were characterized using the major ion at $\mathrm{m} / \mathrm{z} 357$ (Fig. 4d). This ion was more abundant in the DM plants as compared to WT plants, and appeared to be present at about the abundance as H-lignin in DM plants. Marker ions and abundance for peak characteristics for the incorporation of coniferyl aldehyde $m / z 354$ (G-indene; Fig. 4e), and sinapyl aldehydes $m / z 323$ (S-indene; Fig. 5f), were greater in DM plants as compared to WT. Total ion spectra for G- and $\mathrm{S}$-indene are shown in Fig. $4 \mathrm{~g}$, h, respectively, to indicate that these spectra contained the ion characteristics of these compounds $(\mathrm{m} / \mathrm{z} 293$ and 354 for G-indene and $\mathrm{m} / \mathrm{z}$ 323 and 384 for S-indene; Kim et al. 2002; Barrière et al. 2004).

G-lignin was the dominant subtype in WT plants from both sorghum backgrounds, and RTx430 WT plants possessed greater amounts of G-lignin as compared to the Wheatland WT plants (Fig. 5a). bmr mutations were associated with strongly reduced levels of G-lignin in the $b m r-6$ and DM plants and to a lesser extent in the $b m r-12$ plants (Fig. 5a). RTx430 plants contained more G-lignin as compared to the respective Wheatland near-isogenic lines. Abundance of ion $(\mathrm{m} / \mathrm{z}, 299)$ characteristic of S-lignin was lower than those observed for G-lignin in both backgrounds (Fig. 5b). The calculated S/G ratio for the Wheatland WT plants was 0.59 as compared to 0.46 for the RTx430 WT plants. Levels of S-lignin were highly reduced in the $b m r$ and DM plants in both backgrounds (Fig. 5b). RTx430 $b m r-6$ plants contained approximately $70 \%$ more S-lignin as compared to the Wheatland $b m r-6$ plants $\left(2.38 \times 10^{10}\right.$ vs. $7.48 \times 10^{9}$ area units; Fig. 5 b). DM plants in either 
Fig. 4 Major ions and ion abundance of diagnostic markers of lignin detected by GCMS following thioacidolysis of sorghum stems. Black lines in chromatograms (a-f) are for WT (wild-type) plants and gray lines are from DM (double-mutant) plants. Specific ions indicative of (a) G-lignin $(\mathrm{m} / \mathrm{z}$ 269); (b) Slignin $(\mathrm{m} / \mathrm{z}, 299)$; (c) H-lignin $(\mathrm{m} /$ z 239); (d) 5-OHG-lignin $(\mathrm{m} / \mathrm{z}$ 357); (e) G-indene ( $\mathrm{m} / \mathrm{z} 354)$; (f) S-indene $(\mathrm{m} / \mathrm{z}, 323) . \mathbf{g}$, h Total ion spectra for peaks associated with G-indene and S-indene, respectively a G-Lignin, Ion 269 (RTx430)

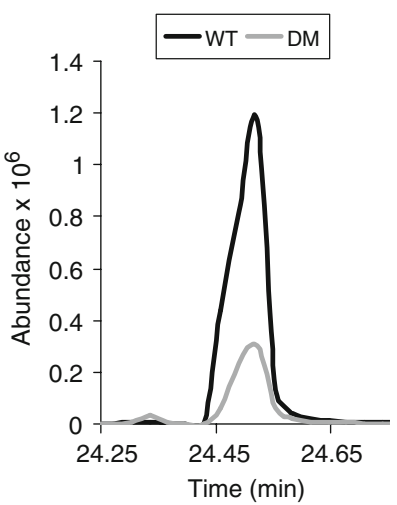

d 5-OHG-Lignin, Ion 357 (RTx430)
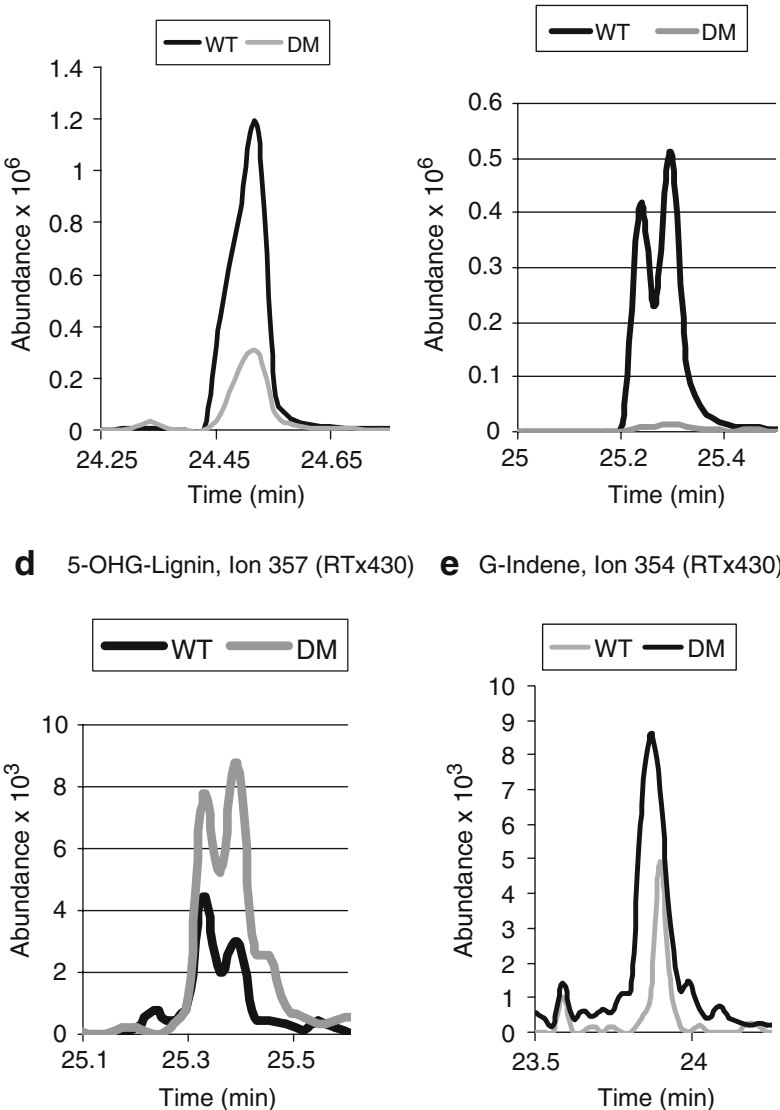

G-Indene, Ion 354 (RTx430)
C H-Lignin, lon $239(\mathrm{RT} \times 430)$

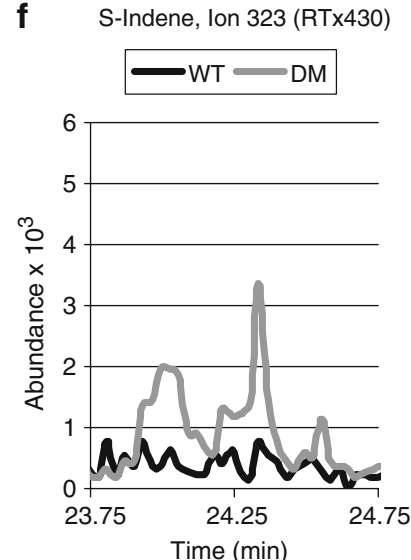

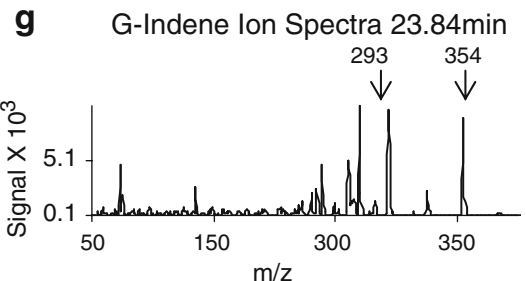

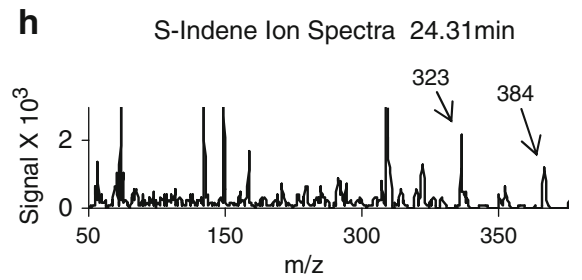

background contained trace levels of S-lignin $(<2 \%$ of WT levels).

Thioacidolysis released ions with $\mathrm{m} / \mathrm{z}, 239$, corresponding to H-lignin units. Abundance of these ions in the WT plants was approximately $2 \%$ of the ions associated with G-lignin (Fig. 5c). Wheatland WT plants contained more apparent $\mathrm{H}$ lignin as compared to RTx430 WT plants. H-lignin levels appeared to be less affected by the presence of the $b m r$ mutations either alone or in combination. In both backgrounds, bmr-12 plants had more H-lignin when compared to the bmr-6 or DM plants (Fig. 5c). Although RTx430 WT plants had lower apparent levels of H-lignin as compared to the Wheatland WT plants, RTx430 bmr and DM near-isogenic plants contained greater levels of H-lignin when compared to their respective Wheatland lines (Fig. 5c).

All the sorghum plants tested contained detectable amounts of 5-OHG-lignin, and S- and G-indenes (arising from the direct incorporation of the corresponding mono- lignals). The apparent distribution and amounts of these forms were generally similar within each sorghum background (Fig. 5d, e). Levels of 5-OHG-lignin ( $\mathrm{m} / \mathrm{z}$ 357) were greatest in $b m r-12$ plants and least in bmr-6 plants. In plants, in either background, levels of signal associated with G- or S-indenes were much lower than that observed for hG-lignin. In contrast, G- and S-indene levels were low in WT and bmr-12 plants, but much higher in bmr-6 and DM plants (Fig. 5d, e). In both backgrounds, the DM plants contained appreciable levels of the three minor lignin forms.

Microscopy of sorghum internodes stained for lignin

To observe how bmr mutations affected spatial lignin deposition and cellular anatomy, internodes from Wheatland bmr and WT plants were sectioned, stained with diazotized nitroaniline, and observed by light microscopy (Fig. 6). In 
Fig. 5 Distribution of major and minor lignin subcomponents in stems of Wheatland and RTx430 near-isogenic plants. a G-lignin; b S-lignin; c H-lignin in Wheatland (white bars) and RTx430 (gray bars). WT wildtype, $D M$ double-mutant. Abundance of ions diagnostic of 5OHG-lignin (white bars), S-indene (black bars), and G-indene (graybars) in Wheatland (d) and RTx430 (e) plants. Data are the pooled means $( \pm$ SEM) of triplicate analyses from two independent extractions
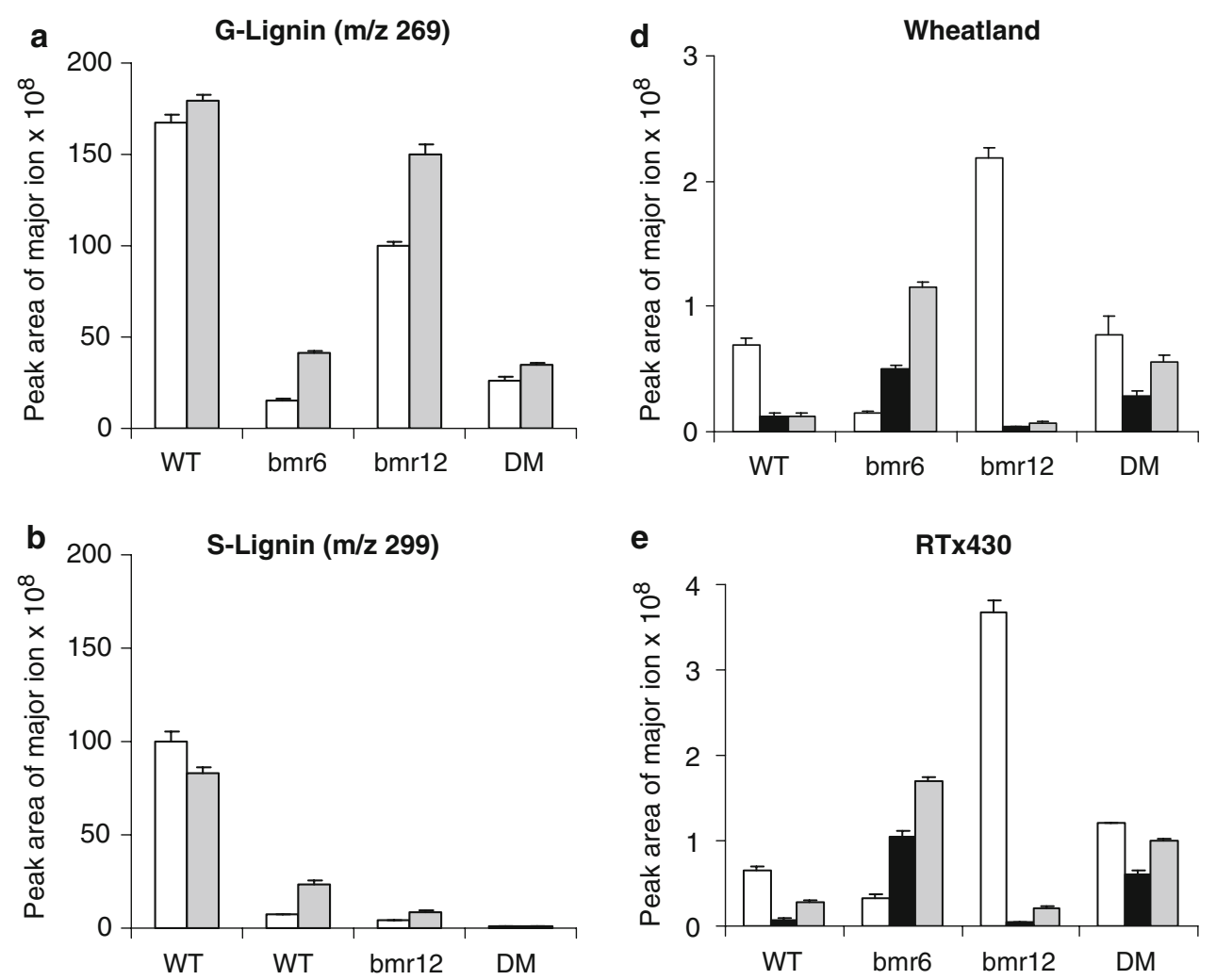

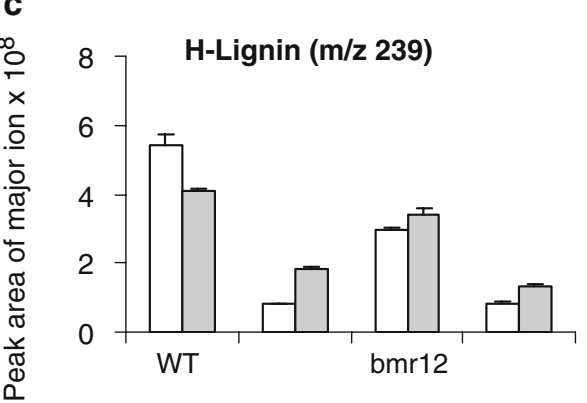

WT plants, the fiber sheath (FS) surrounding the vascular bundles (VB) and the cortical sclerenchyma (CSc, arrows) were well developed and intensely stained uniform brownish-orange. Cell walls of the cortical and pith parenchyma cells (PC) also stained uniformly (Fig. 6a, e). In $b m r-6$ plants, the fiber sheath around vascular bundles was present, but it was not stained as extensively as those of WT plants, and the relative staining intensity of the PC was reduced as compared with WT. Fiber sheath cells in $b m r-6$ plants were bronze in color, and they were larger and stained less intensely than fiber sheath cells in WT plants (Fig. 6b, f). In bmr-12 tissues, the cortical sclerenchyma was diffusely stained with pockets of light orangish-brownstained thick-walled cells congruent to the vascular bundle (Fig. 6c). The fiber sheaths were less developed, composed of larger less uniform cells, and stained a pale reddishbrown (Fig. 6g). The double-mutant internodes were distinct from those of WT, $b m r-6$, and $b m r-12$ plants in that they appeared to be poorly lignified as discerned from a lack of staining with diazotized nitroaniline (Fig. 6d; CSc, arrows). Although the fiber sheath (FS) surrounding the vascular bundles was defined in double-mutant plants, it was composed of fewer cell layers containing large cells staining light-orange (Fig. 6h).

\section{Discussion}

Researchers have previously examined lignin and phenolic signatures in bmr-sorghum plants (Pillonel et al. 1991; Lam et al. 1996; Suzuki et al. 1997; Hatfield et al. 1999; Bout and Vermerris 2003). These studies focused on evaluating components of a single $b m r$ mutant in one genetic background or attempted to compare $b m r$ mutants in different genetic backgrounds. These earlier studies have uncovered some of the structural, biochemical, and molecular aspects 
Fig. 6 Light microscopy of sorghum internodes from Wheatland plants stained with diazotized nitroaniline. (See "Materials and methods.") a, e WT plants showing anatomy and staining of cortical sclerenchyma (CSc, arrows) and fiber sheaths (FS) surrounding vascular bundles (VB). Parenchyma cells (PC) are also labeled. b, $\mathbf{f}$ Section from a $b m r-6$ plant; $\mathbf{c}, \mathbf{g}$ section from a $b m r-12$ plant; $\mathbf{d}, \mathbf{h}$ section from a double-mutant plant. Bars shown in d (also for $\mathbf{a}-\mathbf{c})$ and in $\mathbf{h}(\mathbf{e}-\mathbf{g})$ are equal to $100 \mu \mathrm{m}$
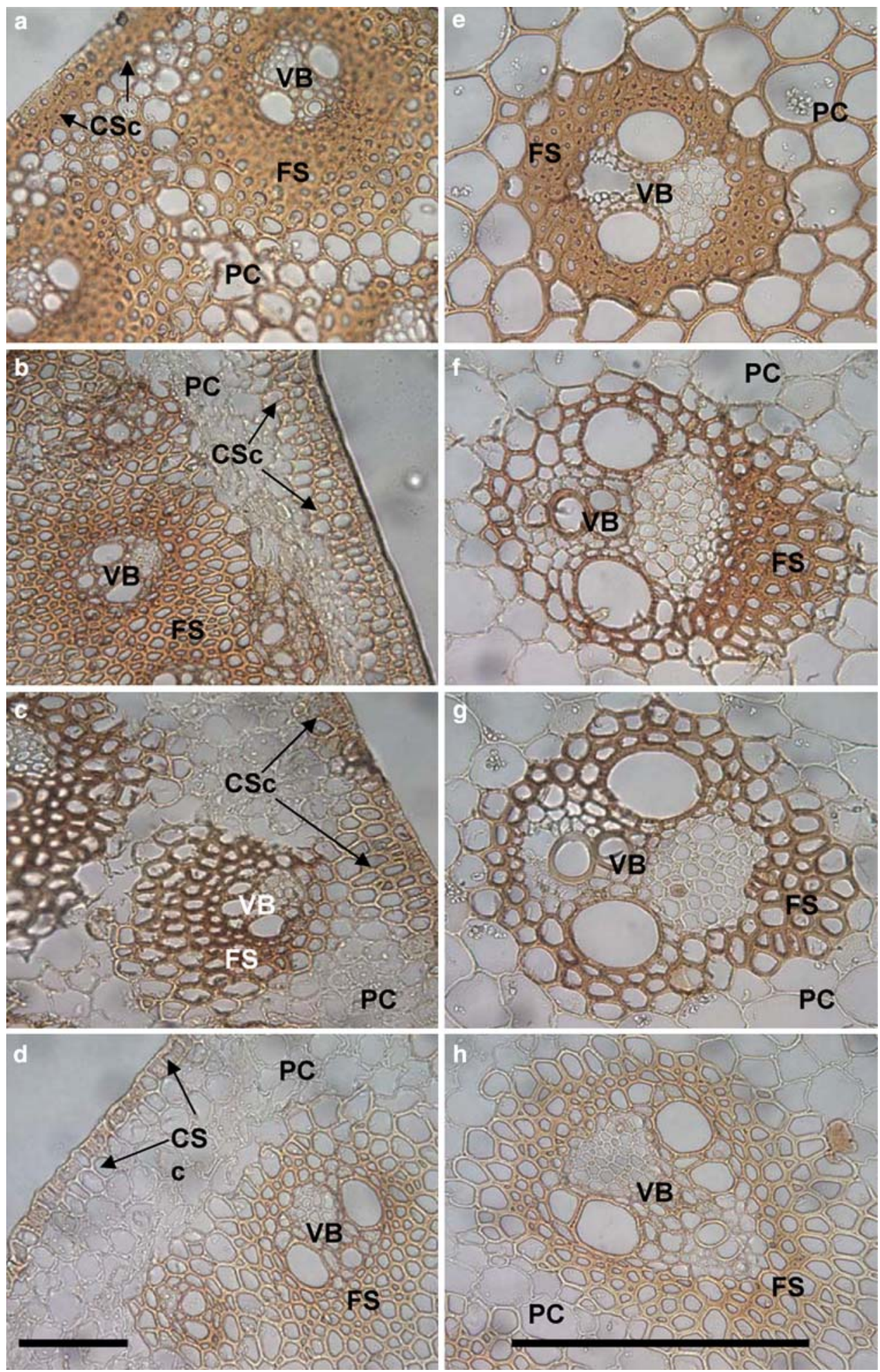

of the sorghum bmr mutants. However, there is little biochemical information on the influence of genetic background on $b m r$ mutations, and it is not known if these mutations would have a synergistic effect on reducing cell wall-associated aromatics and lignin. This study is a first report comparing soluble and insoluble aromatic constitu- ents in the cell walls of stems from near-isogenic lines of two $b m r$ loci, $b m r-6$ and $b m r-12$, independently and together in two different genetic backgrounds, Wheatland and RTx430.

Soluble aromatic profiles of internode extracts were influenced by the developmental stage of the tissues in 
Wheatland plants. Less mature (top) internodes contained more free phenolics, whereas the more mature (bottom) internodes contained lowered levels of free phenolics. This result is likely due to greater lignification in mature internodes (Chen et al. 2002; Casler and Jung 2006) and a presumed loss of free precursors in older tissues.

Across both backgrounds, $b m r-6$ near-isogenic lines displayed the greatest amounts of the different free phenolics and other aromatics, suggesting that the apparent loss in CAD activity was influencing the accumulation of free phenolic components. Lowered CAD activity in $b m r-6$ plants as compared to WT has been reported earlier (Pillonel et al. 1991). In contrast, our data suggest that stem extracts from both the near-isogenic CAD-deficient $b m r-6$ and DM plants in the two different sorghum backgrounds tested had no measureable activity against coniferyl alcohol under the assay conditions employed. However, these assays may not have been sensitive enough to detect residual levels of CAD activity, nor CAD proteins with low affinity for coniferyl alcohol. Overall, our results support the hypothesis that BMR-6 encodes for a CAD protein that is specifically involved in stem lignification, as indicated by the overall loss of G- and S-lignin in stem cell walls from $b m r-$ 6 and DM plants. Lowered levels of sinapyl and coniferyl alcohols would be expected to reduce the availability of pCA esters of these alcohols for incorporation into cell walls (Grabber and Lu 2007), a scenario consistent with our data showing lowered amounts of pCA esters in the cell walls of sorghum $b m r-6$ plants.

Plant CADs occur as a family of related proteins with significant predicted homology in structure and potential function (Kim et al. 2007; Tobias and Chow 2005; Ferrer et al. 2008). In detailed analyses of the Arabidopsis CAD gene family, only two CADs, AtCAD4 and AtCAD5, have been shown to play a role in lignification (Kim et al. 2007), suggesting that there is limited functional overlap between the different CAD proteins present in most plants. Our immunoblot data suggest that the anti-CAD antibodies used could be nonspecific and/or recognized one or more CAD protein not directly affected by the $b m r-6$ mutation. Alternatively, the $b m r-6$ mutation results in the normal accumulation of CAD protein albeit with minimal activity in sorghum $b m r-6$ and DM plants.

For the sorghum genotypes analyzed, reduced or loss of CAD activity (bmr-6) appeared to have shifted the flux of soluble aromatic intermediates toward FA, but had not affected the overall incorporation of esterified FA into the cell walls. However, the exact mechanisms behind these observations remain to be investigated. The maize brown midrib mutant $B m-1$ is phenotypically similar to sorghum bmr-6 (Halpin et al. 1998). In Bm-1, CAD activity is reduced, but not eliminated, and $B m-1$ has been mapped to a region of the maize genome containing a CAD homolog
(Halpin et al. 1998). The sorghum $b m r-6$ mutation has important consequences on stem phenolic and lignin content, and the future cloning and characterization of $B M R-6$ and $b m r-6$ alleles should provide greater biochemical and genetic insights.

Bout and Vermerris (2003) had shown that $b m r-12$ sorghum plants contained a nonsense mutation in a COMT gene, while the present work demonstrated the absence of COMT protein in the $b m r-12$ and DM plants using antiCOMT sera raised in rabbits. A faint crossreaction in stem extracts from RTx430 bmr-12 and DM plants to antiCOMT antibodies generated in guinea pigs was detected. However, the specificity of this antibody to different sorghum COMTs and the potential of these other COMT enzymes to contribute to the synthesis of lignin precursors in the Wheatland and RTx430 plants have not been explored. Interactions between the genetic backgrounds and the $b m r-12$ allele were evidenced by increased levels of soluble aromatic compounds in $b m r-12$ and DM Wheatland plants, but not in the comparable RTx430 near-isogenic lines, and an increase in the G-lignin and H-lignin monomers released by thioacidolysis in RTx430 bmr-12 plants relative to Wheatland $b m r-12$ plants. In contrast, incorporation of pCA esters and G-, S-, and H-lignin monomers into cell walls was enhanced in RTx430 DM plants as compared to Wheatland DM plants, suggesting a differential impact of the $b m r$ traits in different genetic backgrounds. Although the overall biochemical differences between Wheatland and Rtx430 plants are not known, our data indicates that it should be possible to selectively modulate cell wall composition and thereby increase biomass quality by utilizing the most promising combination of the $b m r$ genes and sorghum genetic backgrounds.

Results from thioacidolysis indicate that the loss of COMT (bmr-12) leads to a strong decrease in S-lignin and an enhanced incorporation of 5-OHG lignin, but not G- and $\mathrm{S}$-indenes. These results suggest that sorghum BMR-12 codes for a 5-hydroxyconiferylaldehyde- $O$-methyltransferase, as has been documented for other plants ( $\mathrm{Li}$ et al. 2000; Barrière et al. 2004).

Observed difference in soluble aromatics, wall-bound phenolic esters and lignin components in $b m r$ and DM lines as compared to near-isogenic WT plants indicated that cell wall lignification was impaired in these plants. To analyze if these changes were global or limited to specific tissues, we utilized diazotized nitroaniline (Akin et al. 1990) to stain internode sections. In previous work, diazotized nitroaniline had been shown to react with phenolic acids, aldehydes, and esters and yielding brown- or orange-browncolored products. This histochemical agent stained WT (normal) and bmr-12 sorghum lignin a uniform brown (Akin et al. 1990). In the present work, internode sections from near-isogenic WT, $b m r-6, b m r-12$, and DM plants 
were analyzed. Most cells in WT stems stained a uniform brown, and lignified tissues, such as the cortical sclerenchyma and fiber sheath cells, had well-defined thick cell walls, indicating that these cells contained significant amounts of phenolic and lignin compounds, including pCA (Akin et al. 1990), which was consistent with cell wall phenolic ester and lignin content we detected in these plants. In $b m r-6, b m r-12$, and DM stems, there was less brown coloration of the cortical sclerenchyma, the fiber sheaths surrounding the vascular bundles and in the parenchyma cell walls of the cells. These results were also consistent with lowered levels of pCA esters and lignin observed in these plants. In stem sections from $b m r-6$ plants, many cell walls were stained a reddish-orange, which may be due to an increased ratio of FA to pCA seen for these plants. DM plants exhibited the lightest staining, with incomplete coloration of cell walls, suggesting that accumulation of lignin in the secondary cell wall had been impaired, consistent with the thioacidolysis data on these plants.

In the present study, changes in free phenolic and aromatic profiles, reduced incorporation of phenolic esters and lignin monomers into the cell walls, and the reduced and/or loss of CAD and COMT enzymes specific for the lignin biosynthetic pathway were consistent with what has been observed in reduced lignin mutants in sorghum and other plants (Akin et al. 1986; Pillonel et al. 1991; Bout and Vermerris 2003; Barrière et al. 2004; Pedersen et al. 2005; Shi et al. 2006). Previous studies had indicated that reduction or absence of CAD or COMT activity as a result of brown midrib mutations reduced the total amounts of monolignols synthesized and altered the type of monolignols incorporated into sorghum cell walls (Akin et al. 1986; Pillonel et al. 1991; Lam et al. 1996; Hatfield et al. 1999; Bout and Vermerris 2003). However, in the present study, effects of bmr double-mutants on wall-bound aromatics in the two sorghum backgrounds were unexpected. These results indicate the presence of a locus (loci) unique to either RTx430 or Wheatland that affects the biosynthesis or incorporation of pCA and FA in the presence of both $b m r-6$ and $b m r-12$; similar loci have also been reported in maize (Guillaumie et al. 2007). Recent reports with maize suggest that many genes are differentially expressed in the different $b m$ plants as compared to WT plants, and the proteins encoded for by these genes are likely to influence cell morphology and cell wall composition (Shi et al. 2006, 2007). Our data indicate that the unique interactions of the $b m r$ alleles, especially together, with the different sorghum genetic backgrounds are exploitable, and could be utilized to develop sorghum plants with biomass qualities designed to fit appropriate conversion platforms.

Acknowledgments We thank Pat O'Neill and John Toy for technical assistance.

\section{References}

Akin DE, Hanna WW, Snook ME, Himmelsbach DS, Barton FEI, Windham WR (1986) Normal-12 and brown midrib-12 sorghum. II. Chemical variations and digestibility. Agron J 78:832-837

Akin DE, Hartley RD, Morrison WHI, Himmelsbach DS (1990) Diazonium compounds localize grass cell wall phenolics: relation to wall digestibility. Crop Sci 30:985-989

Anterola AM, Lewis NG (2002) Trends in lignin modification: a comprehensive analysis of the effects of genetic manipulations/mutations on lignification and vascular integrity. Phytochemistry 61:221-294

Barrière Y, Ralph J, Mechin V, Guillaumie S, Grabber JH, Argillier O, Chabbert B, Lapierre C (2004) Genetic and molecular basis of grass cell wall biosynthesis and degradability. II. Lessons from brown-midrib mutants. C R Biol 327:847-860

Boerjan W, Ralph J, Baucher M (2003) Lignin biosynthesis. Annu Rev Plant Biol 54:519-546

Bout S, Vermerris W (2003) A candidate-gene approach to clone the sorghum Brown midrib gene encoding caffeic acid $O$-methyltransferase. Mol Genet Genomics 269:205-214

Casler MD, Jung HJG (2006) Relationships of fibre, lignin, and phenolics to in vitro fibre digestibility in three perennial grasses. Anim Feed Sci Technol 125:151-161

Casler MD, Buxton DR, Vogel KP (2002) Genetic modification of lignin concentration affects fitness of perennial herbaceous plants. Theor Appl Genet 104:127-131

Chen F, Dixon RA (2007) Lignin modification improves fermentable sugar yields for biofuel production. Nat Biotechnol 25:759-761

Chen L, Auh C, Chen F, Cheng X, Aljoe H, Dixon RA, Wang Z (2002) Lignin deposition and associated changes in anatomy, enzyme activity, gene expression, and ruminal degradability in stems of tall fescue at different developmental stages. J Agric Food Chem 50:5558-5565

Cherney JH, Cherney DJR, Akin DE, Axtell JD (1991) Potential of brown-midrib, low-lignin mutants for improving forage quality. Adv Agron 46:157-198

Dalton DA, Baird LM, Langeberg L, Taugher C, Anyan WR, Vance CP, Sarath G (1993) Subcellular localization of oxygen defense enzymes in soybean (Glycine max [L]. Merr) root nodules. Plant Physiol 102:481-487

Dien BS, Jung HG, Vogel KP, Casler MD, Lamb JFS, Weimer PJ, Iten L, Mitchell RB, Sarath G (2006) Chemical composition and response to dilute-acid pretreatment and enzymatic saccharification of alfalfa, reed canarygrass, and switchgrass. Biomass Bioener 30:880-891

Dixon RA, Chen F, Guo D, Parvathi K (2001) The biosynthesis of monolignols: a "metabolic grid", or independent pathways to guaiacyl and syringyl units? Phytochemistry 57:1069-1084

Ferrer JL, Austin MB, Stewart C Jr, Noel JP (2008) Structure and function of enzymes involved in the biosynthesis of phenylpropanoids. Plant Physiol Biochem 46:356-370

Grabber JH, Lu F (2007) Formation of syringly-rich lignins in maize as influenced by feruloylated xylans and p-coumaroylated monolignols. Planta 226:741-751

Grabber JH, Jung GA, Hill RR Jr (1991) Chemical composition of parenchyma and sclerenchyma cell walls isolated from orchardgrass and switchgrass. Crop Sci 31:1058-1065

Guillaumie S, Pichon M, Martinant JP, Bosio M, Goffner D, Barriere Y (2007) Differential expression of phenylpropanoid and related genes in brown-midrib bm1, bm2, bm3, and bm4 young near-isogenic maize plants. Planta 226:235-250

Halpin C, Holt K, Chojecki J, Oliver D, Chabbert B, Monties B, Edwards K, Barakate A, Foxon GA (1998) Brown-midrib maize (bm1) - a mutation affecting the cinnamyl alcohol dehydrogenase gene. Plant J 14:545-553 
Hatfield RD, Wilson JR, Mertens DR (1999) Composition of cell walls isolated from cell types of grain sorghum stems. J Sci Food Agric 79:891-899

Humphreys JM, Hemm MR, Chapple C (1999) New routes for lignin biosynthesis defined by biochemical characterization of recombinant ferulate 5-hydroxylase, a multifunctional cytochrome P450dependent monooxygenase. Proc Natl Acad Sci USA 96:1004510050

Iiyama K, Lam TBT, Stone B (1990) Phenolic acid bridges between polysaccharides and lignin in wheat internodes. Phytochemistry 29:733-737

Katsuyoshi H, Tsutsumi Y, Nishida T (2003) Treatment of poplar callus with ferulic and sinapic acids I: incorporation and enhancement of lignin biosynthesis. J Wood Sci 40:333-338

Kim H, Ralph J, Lu F, Pilate G, Leplé JC, Pollet B, Lapierre C (2002) Identification of the structure and origin of thioacidolysis marker compounds for cinnamyl alcohol dehydrogenase deficiency in angiosperms. J Biol Chem 277:47412-47419

Kim SJ, Kim KW, Cho MH, Franceschi VR, Davin LB, Lewis NG (2007) Expression of cinnamyl alcohol dehydrogenases and their putative homologues during Arabidopsis thaliana growth and development: lessons for database annotations? Phytochemistry 68:1957-1974

Laemmli UK (1970) Cleavage of structural proteins during the assembly of the head of bacteriophage $\mathrm{T}_{4}$. Nature 227:680-685

Lam TBT, Iiyama K, Stone BA (1996) Lignin and hydroxycinnamic acids in walls of brown midrib mutants of sorghum, pearl millet and maize stems. J Sci Food Agric 71:174-178

Lapierre C, Monties B, Ronaldo C (1986) Thioacidolysis of poplar lignins: identification of monomeric syringyl products and characterization of guaiacyl-syringyl lignin fractions. Holzforschung 40:113-118

Li L, Popko JL, Umezawa T, Chiang VL (2000) 5-Hydroxyconiferylaldehyde modulates enzymatic methylation for syringyl monolignol formation, a new view of monolignols biosynthesis in angiosperms. J Biol Chem 275:6537-6545

Littell RC, Milliken GA, Stroup WW, Wolfinger RD (1996) SAS system for mixed models. SAS Institute, Cary

Oliver AL, Klopfenstein TJ, Grant RJ, Pedersen JF (2005a) Comparative effects of the sorghum bmr- 6 and bmr- 12 genes. I. Forage sorghum yield and quality. Crop Sci 45:2234-2239

Oliver AL, Klopfenstein TJ, Jose HD, Pedersen JF, Grant RJ (2005b) Comparative effects of the sorghum bmr- 6 and bmr-12 genes. II. Grain yield, stover yield, and stover quality in grain sorghum. Crop Sci 45:2240-2245

Pedersen JF, Funnell DL, Vogel KP (2005) Impact of reduced lignin on plant fitness. Crop Sci 45:812-819
Pedersen JF, Funnell D, Toy JJ, Oliver AL, Grant RJ (2006) Registration of 12 grain sorghum genetic stocks near-isogenic for the brown midrib genes $b m r-6$ and $b m r-12$. Crop Sci 46:491-492

Pedersen JF, Toy JJ, Funnell DL, Sattler SE, Oliver AL, Grant RA (2008) Registration of BN611, AN612, BN612, and RN613 sorghum genetic stocks with stacked $b m r-6$ and $b m r-12$ genes. J Plant Registr 2:258-262

Pillonel C, Mulder MM, Boon JJ, Forster B, Binder A (1991) Involvement of cinnamyl-alcohol dehydrogenase in the control of lignin formation in Sorghum bicolor L. Moench. Planta 185:538-544

Rastogi S, Dwivedi UN (2008) Manipulation of lignin in plants with special reference to $O$-methyltransferase. Plant Sci 174:264-277

Sarath G, Baird LM, Vogel KP, Mitchell RB (2007) Internode structure and cell wall composition in maturing tillers of switchgrass (Panicum virgatum. L). Bioresour Technol 98:2985-2992

Sarath G, Mitchell RB, Sattler SE, Funnell D, Pedersen JF, Graybosch RA, Vogel KP (2008) Opportunities and roadblocks in utilizing forages and small grains for liquid fuels. J Ind Microbiol Biotechnol. doi:10.1007/s10295-007-0296-3

Schmer MR, Vogel KP, Mitchell RB, Perrin RK (2008) Net energy of cellulosic ethanol from switchgrass. Proc Natl Acad Sci USA 105:464-469

Shadle G, Chen F, Srinivasa Reddy MS, Jackson L, Nakashima J, Dixon RA (2007) Down-regulation of hydroxycinnamoyl CoA: shikimate hydroxycinnamoyl transferase in transgenic alfalfa affects lignification, development and forage quality. Phytochemistry 68:1521-1529

Shi C, Koch G, Ouzunova M, Wenzel G, Zein I, Lubberstedt T (2006) Comparison of maize brown-midrib isogenic lines by cellular UV-microspectrophotometry and comparative transcript profiling. Plant Mol Biol 62:697-714

Shi C, Uzarowska A, Ouzunova M, Landbeck M, Wenzel G, Lubberstedt T (2007) Identification of candidate genes associated with cell wall digestibility and eQTL (expression quantitative trait loci) analysis in a Flint $\times$ Flint maize recombinant inbred line population. BMC Genomics 8:22

Suzuki S, Lam TBT, Iiyama K (1997) 5-Hydroxyguaiacyl nuclei as aromatic constituents of native lignin. Phytochemistry 46:695-700

Tobias CM, Chow EK (2005) Structure of the cinnamyl-alcohol dehydrogenase gene family in rice and promoter activity of a member associated with lignification. Planta 220:678-688

Xiang P, Haas E, Zeece M, Markwell J, Sarath G (2004) C-terminal 23 $\mathrm{kD}$ polypeptide of soybean Gly $\mathrm{m} \mathrm{Bd} 28 \mathrm{~K}$ is a potential allergen. Planta 220:56-63

Zuo Y, Wang C, Zhan J (2002) Separation, characterization, and quantitation of benzoic and phenolic antioxidants in American cranberry Fruit by GC-MS. J Agric Food Chem 50:3789-3794

Suppplemental material follows .... 


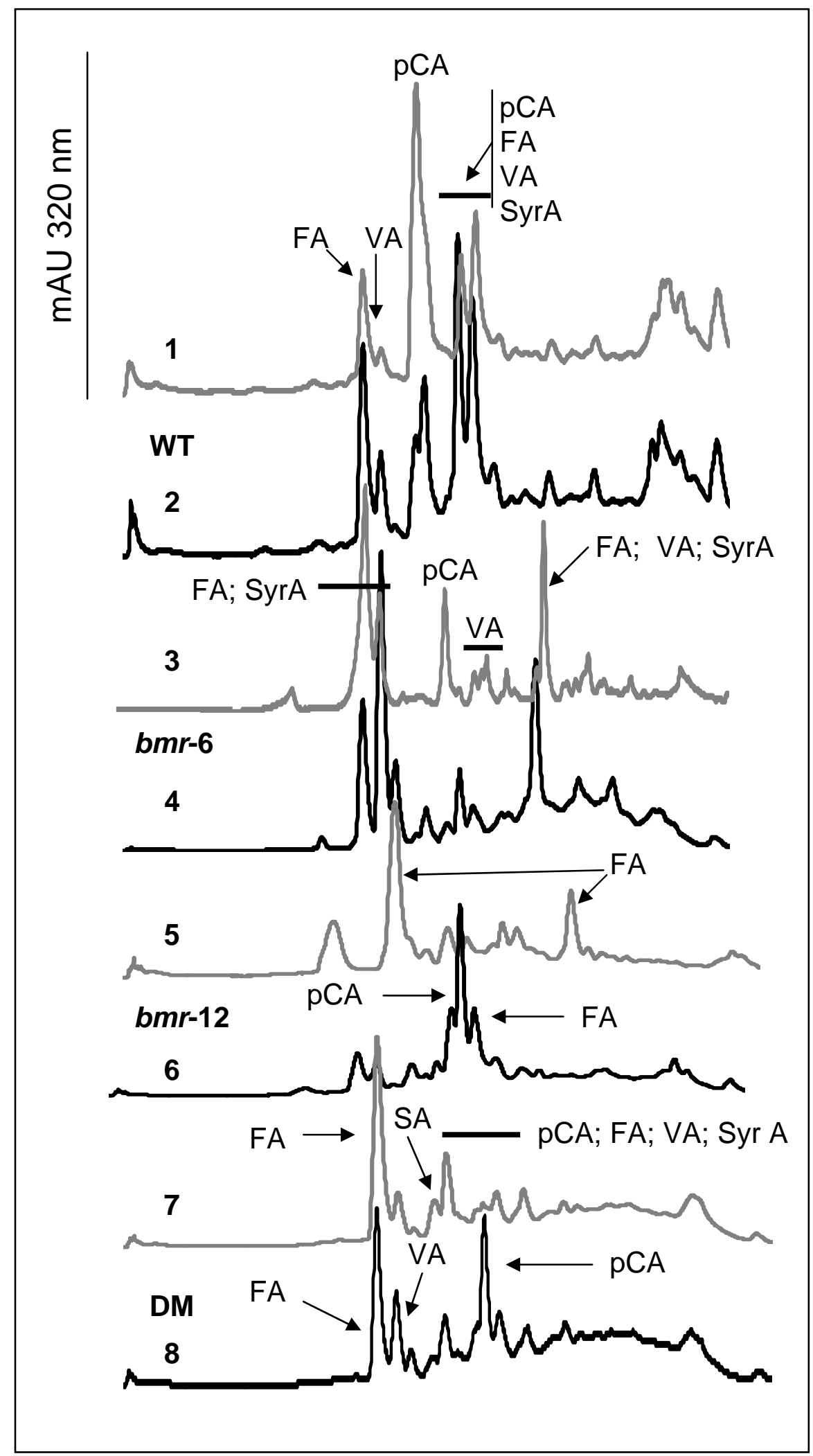

Palmer et al. Planta. Fig.S1 
Fig. S1. HPLC profiles of soluble phenolics extracted from immature and mature internodes of sorghum plants of cv Wheatland near isogenic lines. Traces 1 and 2 WT, immature and mature internodes respectively; Traces 3 and $4 \mathbf{b m r - 6}$, immature and mature internodes respectively; Traces 5 and 6 , bmr-12, immature and mature internodes respectively; Traces 7 and $8 \mathrm{DM}$, immature and mature internodes respectively. Arrows indicate the different phenolic acids detected by GCMS following alkaline hydrolysis of each peak. pCA = 4-Coumaric acid, FA = ferulic acid, SyrA = syringic acid, VA = vanillic acid $\mathrm{DM}=$ double mutant. Methanolic extracts obtained from dried, ground internode tissues were analyzed by HPLC. Column effluent was monitored at $320 \mathrm{~nm}$. 